\title{
Status and conservation of coral reefs in Costa Rica
}

\author{
Jorge Cortés ${ }^{1,2}$, Carlos E. Jiménez ${ }^{1}$, Ana C. Fonseca ${ }^{1,3}$ \& Juan José Alvarado ${ }^{1}$ \\ 1. Centro de Investigación en Ciencias del Mar y Limnología (CIMAR), Ciudad de la Investigación, Universidad de \\ Costa Rica, San Pedro, 11501-2060 San José, Costa Rica; jorge.cortes@ucr.ac.cr \\ 2. Escuela de Biología, Universidad de Costa Rica, San Pedro, San José, Costa Rica. \\ 3. World Wildlife Fund (WWF), San José, Costa Rica, Interlink \#718, P.O. Box 02-5635, Miami, Florida 33102, USA.
}

Received 30-VIII-2009. Corrected 03-X-2009. Accepted 12-XII-2009.

\begin{abstract}
Costa Rica has coral communities and reefs on the Caribbean coast and on the Pacific along the coast and off-shore islands. The Southern section of the Caribbean coast has fringing and patch reefs, carbonate banks, and an incipient algal ridge. The Pacific coast has coral communities, reefs and isolated coral colonies. Coral reefs have been seriously impacted in the last 30 years, mainly by sediments (Caribbean coast and some Pacific reefs) and by El Niño warming events (both coasts). Monitoring is being carried out at three sites on each coast. Both coasts suffered significant reductions in live coral cover in the 1980's, but coral cover is now increasing in most sites. The government of Costa Rica is aware of the importance of coral reefs and marine environments in general, and in recent years decrees have been implemented (or are in the process of approval) to protect them, but limited resources endanger their proper management and conservation, including proper outreach to reef users and the general public. Rev. Biol. Trop. 58 (Suppl. 1): 33-50. Epub 2010 May 01.
\end{abstract}

Key words: coral reefs, Costa Rica, monitoring, GCRMN, conservation, management.

Costa Rica has coral reefs on the Caribbean coast and on the Pacific side (coast and off-shore islands). The Caribbean coast is $212 \mathrm{~km}$ long and consists mainly of high-energy sandy beaches that on the Southern section are interrupted by carbonate promontories (Fig. 1). These promontories are made up primarily of fossil reefs (Pleistocene, Holocene), and beachrock in some sections. Extant reefs develop on top of these rocky outcrops (Cortés \& Guzman 1985, Cortés \& Jiménez 2003a). Three coral reef areas are recognized on the Caribbean coast: 1) fringing reefs between Moín and Limón, 2) fringing and patch reefs, and carbonate banks at Cahuita National Park, and 3) fringing and patch reefs, carbonate banks, and incipient algal ridge between Puerto Viejo and Punta Mona (Fig. 1). Seasonal variability is minimum along this coast, with rains year round and no upwelling. Most of the touristic activity on the Southern Caribbean coast of Costa Rica is oriented toward the reefs, as are also the fisheries.

The Pacific coast of Costa Rica is $1160 \mathrm{~km}$ long, and has a high diversity of habitats: rocky shores of a wide variety of rock types, sandy beaches of several compositions and grain size, mangrove forests, estuaries, a tropical fjord, islands of various sizes, and several gulfs and bays (Fig. 2). The northern section of the coast (Gulf of Papagayo) is characterized by a dry tropical forest, with a very dry season from December to April, and a rainy season from May to November. This part of the coast is exposed to seasonal upwelling (McCreary et al. 1989) during the dry season due to the crossing the isthmus of Trade Winds. The central and southern coast is covered with tropical rain forest, with a transition zone in between in the Central Pacific coast. Coral communities, reefs and isolated coral colonies can be found 


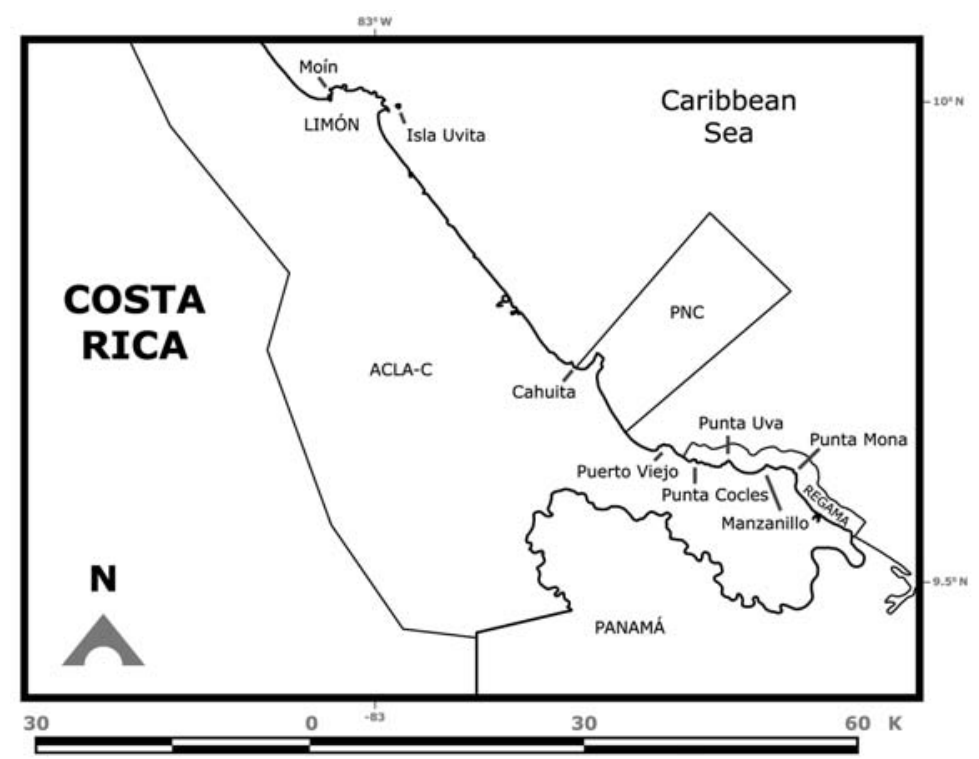

Fig. 1. Caribbean coast of Costa Rica, monitoring sites and Marine Protected Areas. Codes: PNC=Parque Nacional Cahuita; REGAMA=Refugio Nacional de Vida Silvestre Gandoca-Manzanillo.

along the Pacific of Costa Rica, which has been divided into eight regions (Cortés \& Jiménez 2003b): 1) Santa Elena, in the Northern section of the coast next to the border with Nicaragua; 2) Bahía Culebra, to the South of Santa Elena and North of Península de Nicoya; 3 ) Península de Nicoya, mainly the seaward side of the peninsula, since the inner section is an estuarine environment with very little coral growth; 4) Pacífico Central, extends from the East end of Golfo de Nicoya to the largest mangrove area of Costa Rica, the Sierpe-Térraba complex; 5) Península de Osa, the outer section and part of the entrance to Golfo Dulce; 6) Golfo Dulce, includes the reefs within the gulf; and offshore islands: 7) Isla del Caño, $15 \mathrm{~km}$ from the coast, and 8) Isla del Coco, more than $500 \mathrm{~km}$ from the coast (Fig. 2).

\section{STATUS OF THE CORAL REEF BENTHOS CARIBBEAN}

Moín-Limón: Fringing reefs and carbonate platforms are found in this section of the coast which is subject to heavy wave action, with the largest reefs growing on the leeward side of the islands. This area is exposed to freshwater runoff, sewage, petroleum pollution and solid wastes from the main ports on the Caribbean (Mata et al. 1987, Guzman \& Jiménez 1992, Guzman \& García 2002, Acuña-González et al. 2004). The coast between Moín and the Port of Limón is bordered by a carbonate platform that extends from above the upper tidal zone down to $15 \mathrm{~m}$ depth (Cortés \& Guzman 1985). The submerged platform is covered with algae, hydroids, sponges and isolated corals. The most abundant corals in 1983, when the area was surveyed, were: $P$. astreoides and A. agaricites forma purpurea (Cortés \& Guzman 1985). Beyond 15m depth the bottom consisted of soft mud (Cortés 1998). Isla Uvita is off the Port of Limón (Fig. 1), but a strong current separates it from the port and its pollution. So, it is possible to observe welldeveloped reefs around the island. The east side had an extensive carbonate platform, with microatolls of Siderastrea siderea in the lagoon 


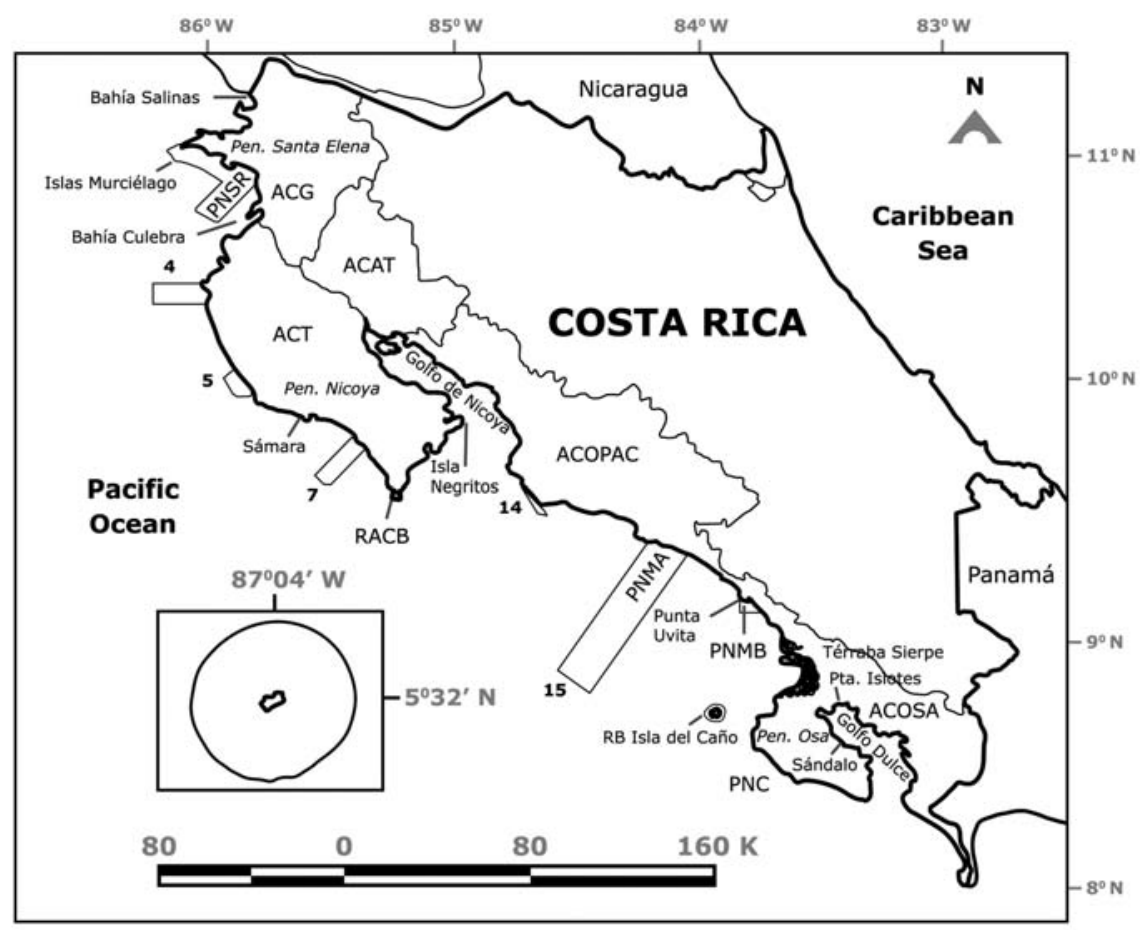

Fig. 2. Pacific coast of Costa Rica, monitoring sites and Marine Protected Areas. Codes: ACG= Área de Conservación Guanacaste; ACM Isla del $\mathrm{Coco}=$ Área de Conservación Marina Isla del Coco; $\mathrm{ACOPAC}=$ Área de Conservación Pacífico Central; $\mathrm{ACOSA}=$ Área de Conservación de Osa; $\mathrm{ACT}=$ Área de Conservación Tempisque; PNC $=$ Parque Nacional Corcovado; PNMA= Parque Nacional Manuel Antonio; $\mathrm{PNMB}=$ Parque Nacional Marino Ballena; PNSR= Parque Nacional Santa Rosa; RACB= Reserva Absoluta Cabo Blanco; RB Isla del Caño= Reserva Biológica Isla del Caño.

that was further exposed with the 1991 Limón Earthquake (Cortés et al. 1992). A monitoring station was established in 2005 in the west side, coral cover was very low and sponges were dominant (Fonseca et al. 2006a).

Cahuita: The largest fringing reef of the Caribbean in the country is located at Parque Nacional Cahuita (Fig. 1). This reef consists of three barriers; the outer barrier, stretching for $5 \mathrm{~km}$ from the Western side of Punta Cahuita, to the Eastern side, it is separated from the coast between $100 \mathrm{~m}$ and $2 \mathrm{~km}$. Between this barrier and the coast there is a small fringing reef, about $500 \mathrm{~m}$ long and within $100 \mathrm{~m}$ from the shore, called the inner crest. Finally, a $100 \mathrm{~m}$ barrier is located of the Western end of the reef (Cortés
\& Risk 1984, 1985, Cortés \& Guzman 1985). Partch reefs are found within the lagoon and carbonate banks off shore. The coral reef at Cahuita had been degrading during the last 30 years due to siltation, other anthropogenic impacts and natural causes (some of them exacerbated by human activity): massive death of organisms, earthquake, and warming events. Live coral coverage decreased from $40 \%$ in the early 1980 's to $10 \%$ in the early 1990's (Cortés 1994). Using the AGRRA surveying protocol, live coral was $2-3 \%$ in the late 1990's (Fonseca 2003). The reef of Cahuita has been monitored since 1999 using the CARICOMP monitoring protocol, and in recent years with funding from the Southern Tropical America-Global Coral Reef Monitoring Network (STA-GCRMN) node. At the 
CARICOMP site, live coral increased slightly from around $15 \%$ to $17 \%$ in 2004 , however turf algal cover has increased significantly (Fonseca et al. 2006a, Fig. 3).

The populations of the black sea urchin, Diadema antillarum, which were decimated in the early 1980's in Costa Rica and wider Caribbean (Lessios et al. 1984, Murillo \& Cortés 1984) are recovering. Before the 1983 mass mortality densities were 3.6 to $8.8 \mathrm{ind} / \mathrm{m}^{2}$ (Valdez \& Villalobos 1978), after the mortality densities were 0.25 to $2 \mathrm{ind} / \mathrm{m}^{2}$. By 1992 it had reached $0.001 \mathrm{ind} / \mathrm{m}^{2}$ (Cortés 1994) and in 2004, 0.3 to $0.7 \mathrm{ind} / \mathrm{m}^{2}$ (Alvarado et al. 2004, Fonseca et al. 2006a). The increase in Diadema may be contributing to the recovery of the reef at Cahuita (Wyckoff \& Cortés unpubl. data). Similar observations were done by Myhre \& AcevedoGutiérrez (2007) in Manzanillo, in which live coral cover has increased. Mean while, Echinometra viridis decreased significantly between 1999 and 2004, from 2 to $0.07 \mathrm{ind} / \mathrm{m}^{2}$ at the CARICOMP site (Fonseca et al. 2006a).

Puerto Viejo-Punta Mona: Around Puerto Viejo the reefs are mostly dead due to siltation, coral extraction for curio-trade, sewage and solid wastes. The reef at Punta Cocles (Fig. 1) had $5 \%$ live coral cover in 1983 , with $S$. siderea as the dominant species (Cortés \& Guzman 1985); in 1988 live coral cover was $12.7 \pm 5 \%$ while in 1995 it was $13.2 \pm 3.6 \%$ (Jiménez \& Cortés unpbl. data). Live coral cover has continued to increase and by 2002 it was $16 \%$ (Fernández \& Alvarado 2004). This increase was probably due to the natural and anthropogenic protection of the reef; it is located far from any large sediment source or rivers and the local people close to the reef protect it because they consider it as part of their homes (Fernández \& Alvarado 2004). From Punta Uva to Punta Mona, the coral reefs are within the Refugio Nacional de Vida Silvestre Gandoca-Manzanillo (Fig. 1), and even though live coral cover is low, reef conditions, in terms of species diversity and health, are good. Fringing reefs are located around the main rocky points, such as Punta Uva, and patch reefs in the lagoons and protected areas from direct wave action. The reef off the town of Manzanillo consisted of an incipient algal ridge (R. Steneck pers. comm.). In 1988, live coral cover overall was around $8 \%$; by the early 1990 s, coral cover

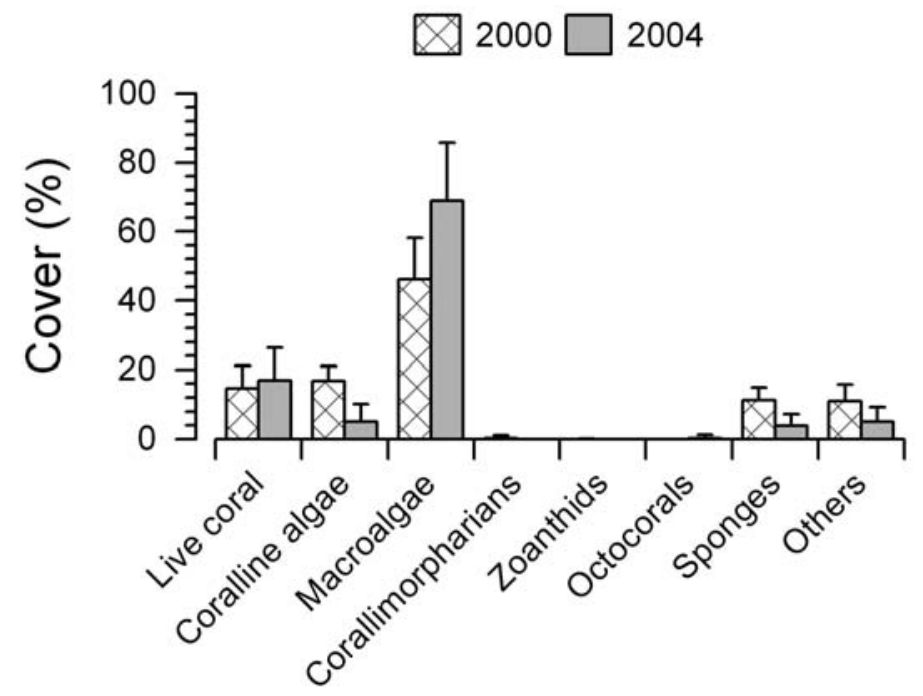

Fig. 3. Average benthic cover ( \pm standard deviation) at Meagershoal, Cahuita National Park. Modified from Fonseca et al. (2006a). 
decreased (ca. 1\%) on the algal ridge than in other sections of the reef (3.4-9\%) (Jiménez \& Cortés unpubl. data). Offshore carbonate banks consisted of hard substrate surrounded by sand (Cortés 1992). Deep offshore walls ( $>25 \mathrm{~m}$ deep) are present off Manzanillo and are colonized by a profusion of octocorals (e.g. Ellisela spp.), platty stony corals (Leptoseris cuculata) and barrel sponges (Xestospongia spp.) (Jiménez \& Cortés unpubl. data, Fonseca pers. obs.). In 1999, using the AGRRA protocol, live coral cover at the forereef platform of Manzanillo was only $2 \%$, recent mortality was $3 \%$, old mortality was $10 \%$ and incidence of diseases was $15 \%$ (Fonseca 2003). In 2003 using the CARICOMP protocol live coral cover at Manzanillo was just over 7\% (Table 1).

\section{PACIFIC COAST AND OFFSHORE ISLANDS}

Bahía Salinas: Located on the North Pacific extreme of Costa Rica and exposed to the seasonal upwelling, the area around Salinas has isolated, but relatively large coral communities made up by Pavona gigantea. Other zooxanthellate corals found were Porites panamensis and a few colonies of Pavona varians. Many azooxanthellate corals have been found: Tubastrea coccinea, Cladopsammia eguchi, Oulangia bradleyi, several species of Astrangia and one species of Phyllangia (Cortés unpubl. data). Many species of algae, octocorals, mollusks and polychaetes have been collected and are now being studied.

Santa Elena: Coral reefs and communities North and South of Península de Santa Elena (mostly within the Área de Conservación Guanacaste, Fig. 2) were described by Cortés (1996/1997). Corals found in low densities in other parts of the Eastern Pacific, formed small patch reefs there, for example Pocillopora eydouxi and Pavona gigantea. Relatively large reefs frameworks built up by Pocillopora damicornis have been found on the North side of Península de Santa Elena. Coral communities formed by mixed assemblages of species
TABLE 1

Average benthic cover ( \pm standard deviation) at Manzanillo in 2003, Gandoca-Manzanillo National Wildlife Refuge. Modified from Fonseca (2003)

$\begin{array}{lc} & \text { Manzanillo }(\mathrm{n}=5) \\ \text { Live coral } & 7.24 \pm 3.41 \\ \text { Coralline algae } & 6.05 \pm 3.79 \\ \text { Non-coralline algae } & 68.80 \pm 8.09 \\ \text { Total algal cover } & 74.85 \pm 8.80 \\ \text { Corallimorpharians } & 0.00 \pm 0.00 \\ \text { Zoanthids } & 0.00 \pm 0.00 \\ \text { Milleporids } & 0.67 \pm 0.13 \\ \text { Octocorals } & 0.96 \pm 0.89 \\ \text { Sponges } & 3.42 \pm 0.60 \\ \text { Others } & 12.86 \pm 4.54\end{array}$

are located on the South of Península de Santa Elena, protected from the full impact of the seasonal upwelling in the region, and from strong wave action. Live coral cover ranged from 47.5 to $95.2 \%$ in 1993-94. Pocillopora damicornis predominated in the shallow sections, while Psammocora stellata predominated the deeper sections.

Transects have been done on a Pocillopora reef off Isla San Pedrillo, Islas Murciélago. This type of reef was characterized by very high coral cover. Data from 1995, 1996, 1997 and 2001 are presented in Figure 4. Live coral cover has stayed in the upper $80 \%$ throughout with a slight decrease in 1997 (Jiménez unpubl. data).

Bahía Culebra: The coral reefs and communities of this area (Fig. 2) were succinctly described by Glynn et al. (1983) and by Cortés \& Murillo (1985), and in more detail by Jiménez (1997, 1998, 2001a), Jiménez et al. (2001), and Jiménez \& Cortés (2003a). Coral reefs and communities have been variably disturbed by natural (El Niño) and anthropogenic impacts (siltation, divers, fishers). Several coral species that were found abundantly in Bahía Culebra in the early 1980's, have become rare because of extraction for aquarium trade (Cortés \& Murillo 1985). Bahía Culebra had rare and unique coral communities and reefs. One in particular, a Leptoseris papyracea reef suffered a high mortality 


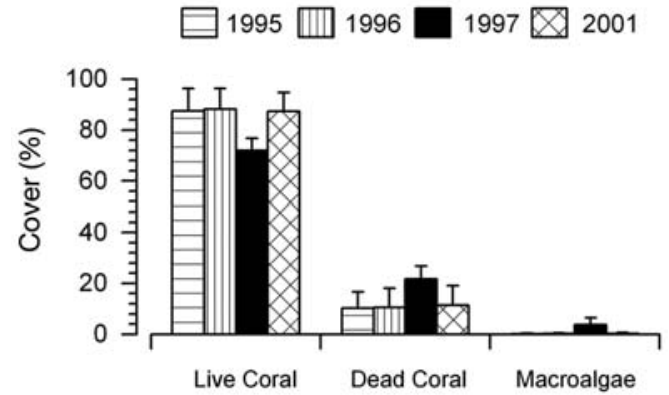

Fig. 4. Average benthic cover and standard deviation on the Pocillopora reef off Isla San Pedrillo, Islas Murciélago.

associated to the 1997/98 El Niño (Jiménez et al. 2001), but it is recovering (Jiménez unpubl. data).

One of the reefs in Bahía Culebra has been monitored since 1994 (Fig. 5). Average live coral cover at three depths was generally higher before the warming and bleaching cycle of 1997/98 and didn't change significantly in the following years. The impact of the warming event was also evident with increasing dead coral and macroalgae covers, with the only exception at $12 \mathrm{~m}$ depth.

Since 2003 the green algae Caulerpa sertulariodes has been spreading aggressively in Bahía Culebra, smothering and killing corals (Fernández \& Cortés 2005, Jiménez unpubl. data). The impact of Caulerpa on the corals was previously observed in 2001 at Bahía Ocotal, 6km South of Bahía Culebra, (Jiménez \& Cortés unpubl. data). Thick mats of Caulerpa extended (ca. 1ha) over live corals between 7 and $15 \mathrm{~m}$ depth, producing bleaching and mortality of colonies. Two years later, Caulerpa reached Bahía Culebra producing extensive mortality of the corals in several areas (Jiménez et al. 2003, Fernández 2007), and of the coral Psammocora in La Penca reef (Bezy et al. 2006). Live coral cover decreased there from $42.7 \pm 20.8 \%$ in 1995 (Jiménez 2001a) to 12.6 $\pm 4.9 \%$ after the Caulerpa invasion (Jiménez et al. unpubl. data). In March 2005, live cover at La Penca was still low (10.3 $\pm 7.2 \%$ ) (Bezy et al. 2006). Fernández (2007) found that the patches of $C$. sertularioides increased in size during
$1994 \square 1997 \square 1998 ख 2001 \square 2003 \square 2005$
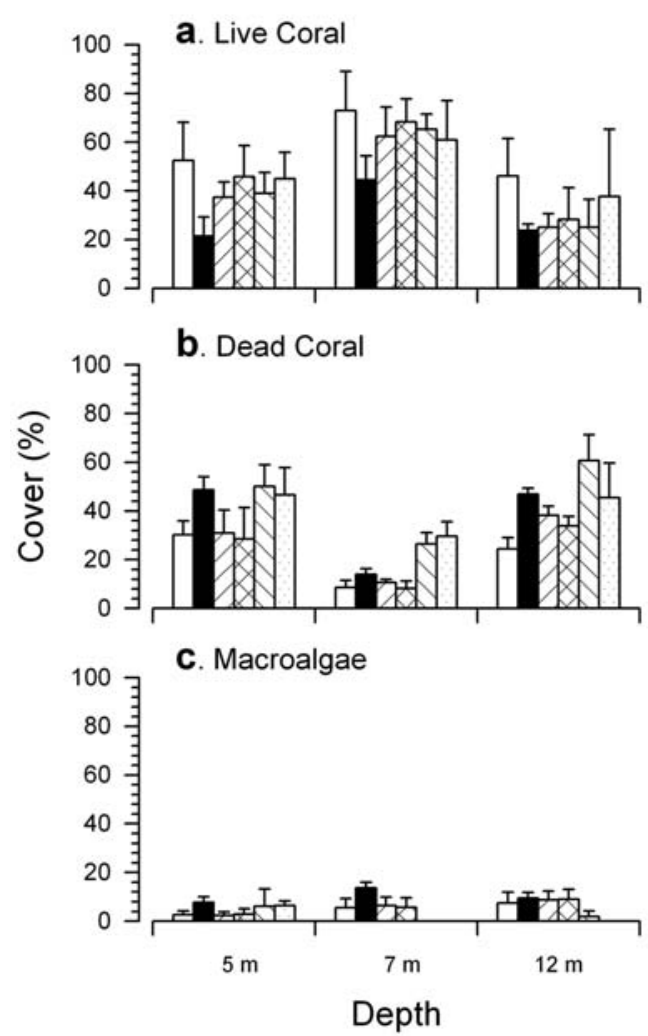

Fig. 5. Average benthic cover and standard deviation at Güiri-güiri, Bahía Culebra.

the upwelling period, and decreased during the non-upwelling period. But, possibly related to eutrophication, the patches were not shrinking much during the non-upweeling period, covering more area every year, and expanding over the entire bay.

Península de Nicoya: This large section of the coast has coral communities, and a few coral reefs (Cortés \& Murillo 1985). Most of the coast is exposed to strong wave action that may preclude the development of coral reefs. However, sheltered from the SW swells, there is an extensive reef, Matapalo (about $1.7 \mathrm{~km}$ long) at the vicinities of Punta Gorda, $12 \mathrm{~km}$ south from Bahía Culebra. Matapalo reef is dominated 
by branching coral species (Pocillopora spp.), which on average have a high live cover $(>50 \%)$, similar to that of Bahía Culebra and Islas Murciélagos (Jiménez in prep.).

In another section of the coast, at Sámara, small Pocillopora, and Porites lobata patch reefs had been observed. Octocorals were abundant on rocky outcrops, and on islands and islets off Península de Nicoya. Patch reefs and coral communities have been observed between Cabo Blanco and the Islas Negritos (Fig. 2), in some areas growing over very extensive dead reefs. Octocorals are abundant on the Islas Negritos. Freshwater runoff in Golfo de Nicoya (Fig. 2) prevents the development of corals in its inner section of the gulf (Cortés \& Jiménez 2003b). Islands in the middle section of the gulf, that many years ago had corals don't have any more because of the increase in freshwater due to water deviation projects in the watershed.

Pacífico Central: The central section of the Pacific coast of Costa Rica has few reefs (Cortés \& Murillo 1985). Isolated corals and small coral communities can be found on rocky outcrops along the coast, including Parque Nacional Manuel Antonio (Fig. 2). Patch reefs of Pavona clavus have been observed to the South.

Rich coral communities have been observed and studied at Parque Nacional Marino Ballena (Alvarado 2004, 2006, Alvarado et al. 2005, 2009). The main reef-builder species was Porites lobata, with a high live coral cover $(40 \%)$ in some sites, follow by Pavona clavus (Fig. 6). Since 1992, the coral communities have been monitored (Fig. 7), showing a decrease in live coral cover due mainly to the El Niño events during the 1990's (Jiménez \& Cortés 2001, 2003b). After 2001, a slow recovery in coral cover has been observed but also a decrease or absence of species that are less resistant to sedimentation (Alvarado unpubl. data). The large fresh water lens between Parque Nacional Marino Ballena and Península de Osa from the Térraba-Sierpe mangrove complex (Fig. 2) inhibits the development of corals in that area.
Península de Osa: The second largest peninsula on the Pacific coast of Costa Rica is Península de Osa, on the Southeastern part of the country (Fig. 2). The coral communities and reefs on Península de Osa were described by Cortés \& Jiménez (1996). A 250m² Pocillopora

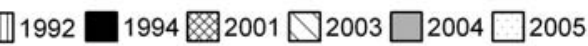

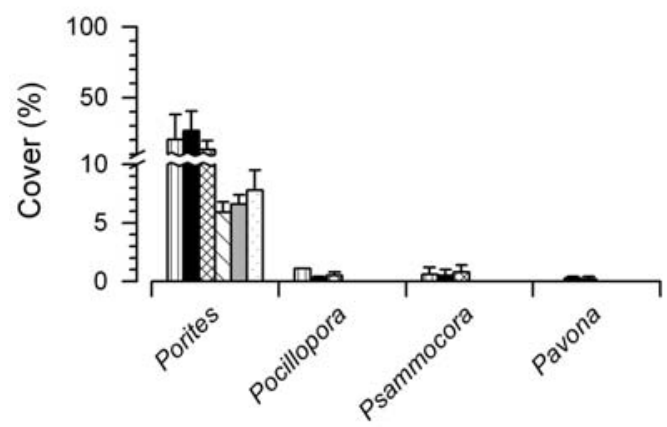

Fig. 6. Percentage average live coral coverage ( \pm standard deviation) at Punta Uvita, Parque Nacional Marino Ballena, 1992-2005. $n=$ total number of transects. $t=$ number of transects where the species was found. $0=$ species not found in the transects. Chain transects (1992, 1994, 2001: Jiménez \& Cortés 2001, 2003), belt transects with $1 \mathrm{~m}^{2}$ quadrat (2003-2005). Table taken from Alvarado et al. (2005).

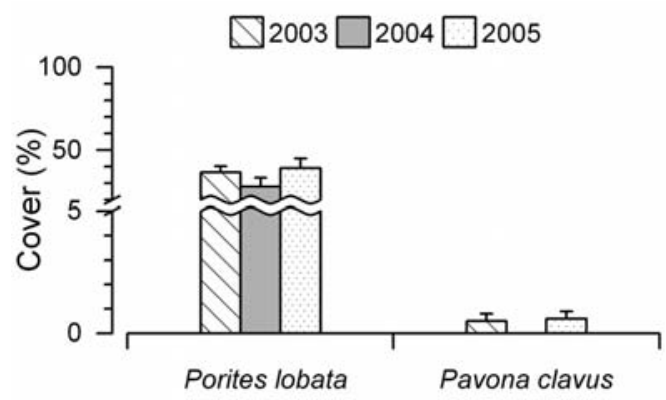

Fig. 7. Percentage average live coral coverage ( \pm standard deviation) at Rocas las Tres Hermanas, Parque Nacional Marino Ballena, 2003-2005. $n=$ total number of transects. $\mathrm{t}=$ number of transects where the species was found. $0=$ species not found in the transects. Belt transects with $1 \mathrm{~m}^{2}$ quadrat (2003-2005). Table taken from Alvarado et al. (2005). 
patch-reef was studied at one site and it consisted of close to $100 \%$ live coral cover of Pocillopora damicornis in 1994. Exposed rocky substrates were covered by octocorals, and isolated corals were found on all rocky outcrops. The area has not been visited since the mid 1990's.

Golfo Dulce: This gulf is located on the Southern part of Costa Rica, and it is about $50 \mathrm{~km}$ long by 10 to $15 \mathrm{~km}$ wide, oriented NW to SE (Fig. 2). It is an enclosed embayment of tectonic origin, with a $60 \mathrm{~m}$ deep sill and depths of $200 \mathrm{~m}$ in the inner section (Hebbeln et al. 1996) that are anoxic. For this reason it is described as a tropical fjord (Hebbeln \& Cortés 2001). Several types of coral reefs and coral communities have been found in the gulf, and they can be divided into two groups, the ones of the inner section of the gulf, and the ones from the outer section (Cortés 1990a, b). The inner Gulf reefs are characterized by live and dead Porites lobata on the reef front and dead Pocillopora damicornis and Psammocora stellata on the reef flat. Coral diversity is low and topographic relief high, with steep reeffronts and sides. Live coral cover ranged from less than $1 \%$ to $8 \%$ in 1987 . The outer Gulf reefs are characterized by a relatively high live coral coverage (range from 29 to 46\%), high coral diversity, and low topographic relief (Cortés 1990b, Cortés \& Guzman 1998).

The reef structure at Punta Islotes started growing 5500 years ago over a basaltic substrate. Between 2500 and 500 years ago reef growth was high, accumulation most of the structure. Around 500 years ago, due to tectonic activity, two rivers started flowing into the inner part of Golfo Dulce, retarding and in some areas stopping reef accretion. In the last 50 years, reef growth has ceased due to the increase in terrigenous sedimentation product of coastal and inland alteration (Cortés et al. 1994).

Between 1992 and 1996 live coral cover at Sándalo (outer reef) decreased from 29 to $17 \%$, while at Punta Islotes (inner reef) it increased from 2 to $10 \%$. Dead coral dominates the substrate. The reef at Sándalo was greatly affected by the sedimentation due to Hurricane Caesar in 1996 (Fonseca et al. 2006b). The structural balance of these reefs was negative, since bioerosion rates were higher, $0.71 \mathrm{~kg} / \mathrm{m}^{2} . \mathrm{y}^{1}$ in Punta Islotes and $2.61 \mathrm{~kg} / \mathrm{m}^{2}$.y in Sándalo, than construction rates, $0.41 \mathrm{~kg} / \mathrm{m}^{2} . y$ in Punta Islotes and $0.56 \mathrm{~kg} / \mathrm{m}^{2} . y$ in Sándalo, resulting in a net reef production of $-0.3 \mathrm{~kg} / \mathrm{m}^{2}$.y in Punta Islotes and $-2.05 \mathrm{~kg} / \mathrm{m}^{2}$.y in Sándalo. If prevailing conditions continue the reef of Punta Islotes will be completely destroyed in 6400 years (Fonseca 1999).

Isla del Caño: This island is located $15 \mathrm{~km}$ offshore from Península de Osa (Fig. 2), and the coral reefs were studied by Guzman (1986). The island had five coral reef flats, ranging in size from 0.8 to 4.2 hectares. These fringing reef flats were mainly built by dead pocilloporid corals, covered by crustose coralline algae, isolated live colonies of pocilloporids and poritids, and microatolls of Porites lobata. The reef slope and base was dominated by the massive coral Porites lobata, which was the predominant species of the island. The shallow sections of the reef were structured mainly by physical factors: wave action, temperature and salinity fluctuations, and low tide exposure. While the deeper sections were controlled by biological interactions: bioerosion, damselfish algal lawns, and corallivores (Guzman 1988, Guzman \& Cortés 1989). These reefs were impacted by the 1982-83 El Niño, with lost of up to $50 \%$ of the live coral coverage (Guzman et al. 1987) followed by phytoplankton blooms that killed shallow pocilloporid reefs (Guzman et al. 1990). Again, during the 1992 and the 1997-1998 El Niño there was extensive bleaching but lower mortality, less than $5 \%$. Pulses of recruitment have been observed after the 1982-83, 1992 and 1997-98 El Niño events (Guzman \& Cortés 2001).

Between 1992 and 1996, live coral at a site on the North side of the island, $10 \mathrm{~m}$ deep, decreased from 30 to $24 \%$, and dead coral was the dominant substrate category (Fonseca et al. 2006b). However, this reef was still a constructive reef with a net production of $2.76 \mathrm{~kg} \mathrm{CaCO} / \mathrm{m}^{2} /$ year, and bioerosion rates being very low $0.002 \mathrm{~kg} \mathrm{CaCO}_{3} / \mathrm{m}^{2} /$ year (Fonseca 1999). 
Isla del Coco: This island is approximately $500 \mathrm{~km}$ southwest of Costa Rica mainland (Cortés 2008). It had the highest number of zooxanthellate corals (17 spp.) on the Pacific of Costa Rica (Cortés \& Guzman 1998). Isla del Coco also had the highest number of azooxanthellate corals, but more than half of this corals were collected in deep waters (Cairns 1991, Cortés unpubl. data). Fringing reefs ranging in size from less than one hectare to more than 50 hectares grew around Isla del Coco. Most of the reefs were constructed by Porites lobata (Bakus 1975, reported as Porites californica) but there were also extensive zones of agariciids: Pavona spp. and Gardineroseris planulata. Macintyre et al. (1992) found that the largest colonies of Porites lobata were between $250 \pm 50$ and $430 \pm 80$ years old, but it is probaly an underestimation of the age the bases of the large colonies bioeroded. Most of the coral died during the 1982-1983 El Niño, in 1987 live coral cover was between 2.6 and $3.5 \%$ (Guzman \& Cortés 1992). The feeding and erosional activity of the sea urchin Diadema mexicanum was concentrated on surviving individuals of the 1982-83 El Niño.

In 2002, Isla del Coco was visited again. Reefs that previously had high densities of $D$. mexicanum were almost complete bioeroded, while reefs that in the 1980's had a high number of coral recruits and had high coral cover in 2002. Live coral cover of several species has increased to $23 \%$ (Fig. 8) and one species, Leptoseris scabra, not seen before, was present and very abundant in some reefs (Guzman \& Cortés 2007).

Populations of corallivores were evaluated in the late 1980's and again in 2002. The density of $A$. planci did not exhibit a significant change between surveys while the density of Arothron meleagris increased significantly overall between 1987 and 2002. The overall average of $D$. mexicanum significantly decreased at all reefs, from $14.5 \mathrm{ind} / \mathrm{ha}$ in 1987 to $0.84 \mathrm{ind} / \mathrm{ha}$ in 2002 (Guzman \& Cortés 2007) (Fig. 9).

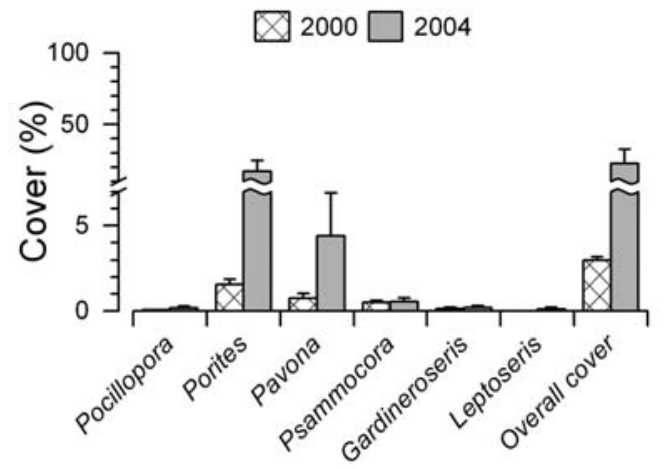

Fig. 8. Mean percent live coral cover ( \pm standard error) by genera in 1987 and 2002 at Isla del Coco (adapted from Table 1 in Guzman \& Cortés 2007).

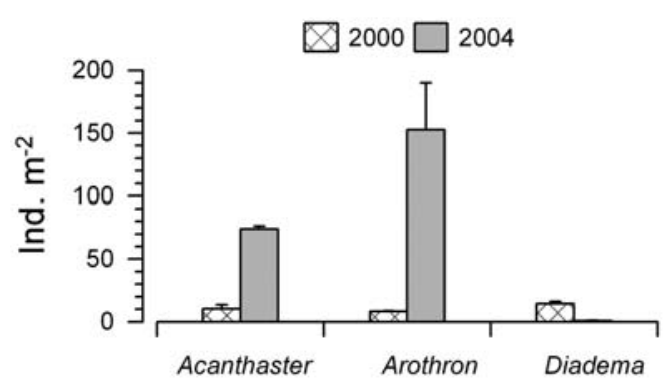

Fig. 9. Population mean ( \pm SE) density comparisons of the corallivores Acanthaster planci and Arothron meleagris (ind $/ \mathrm{ha}^{1}$ ) and of the sea urchin Diadema mexicanum (ind/ $\mathrm{m}^{2}$ ) in 1987 and 2002 at Isla del Coco (adapted from Table 2 in Guzman \& Cortés 2007). Sample size units (n) are number of censuses for corallivores, $\mathrm{m}^{2}$ for Diadema, and number of reefs for grand mean.

\section{STATUS OF CORAL REEF FISHES}

Caribbean: Using a rapid visual technique, Phillips \& Perez-Cruet (1984), found 49 species of reef fishes at Cahuita. They indicated that diversity was lower at Cahuita than at other Caribbean reefs, and attribute this difference to the declining state of the reef at Cahuita. Fonseca \& Gamboa (2003) found 35 species 
of reef fishes in transects done at Cahuita. Fish density, size and diversity were higher in the shallow sites that have higher structural complexity, coral cover and macroalgae abundance (Fonseca \& Gamboa 2003, AGRRA protocol, sampling done in 1999). Damselfishes (mainly Stegastes fuscus and Abudefduf saxatilis) were the most abundant species in shallow $(<4 \mathrm{~m})$ reefs (Fonseca \& Gamboa 2003). In 2004, fish density was low at the CARICOMP site in Cahuita (7-10m), 2.0 fish $100 / \mathrm{m}^{2}(\mathrm{n}=5)$ and only surgeon fish (Acanthurus coeruleus), with a mean size of $15 \mathrm{~cm}$, and a grouper (Epinephelus cruentatus), with a size of $12 \mathrm{~cm}$, were found using the AGRRA protocol. In 2005, more fish were found in Cahuita probably due to more area covered at that time $(\mathrm{n}=10)$, with a total density of 11.8 fish $100 / \mathrm{m}^{2}$. Mean sizes remained similar. Using the REEF protocol in 2005, pomacentrids, acanthurids and labrids were the dominant fishes in Meager Shoal in Cahuita. A total of 36 species of fishes have been encountered in the last two years (Fonseca et al. 2006a). Commercial fishes are smaller and harder to get now than a decade ago (M. Mairena, fisherman, pers. com. 1999).

Pacific: In a study of the reef fishes of Bahía Culebra (Fig. 2), Dominici-Arosemena found 75 species in 28 families (DominiciArosemena 1999, Dominici-Arosemena et al. 2005). The most abundant species was Chromis atrilobata, followed by Thalassoma lucasanum, Abudefduf troschelii and Halichoeres dispilus in shallow waters, and Haemulon steichdachnederi, H. maculicauda and Stegastes flavilatus in deeper waters. Most of the species found showed a positive correlation in their abundance with live coral cover. But, there are signs of problems for the reef fish at Bahía Culebra. On the one hand, work by Jiménez (1998) indicates a progressive degradation of the reef areas between 1996 and 2005. And on the other hand, Dominici-Arosemena (1999) and Dominici-Arosemena et al. (2005) found that because of fish extraction, there is a reduction of terminal males of Thalassoma lucasanum, and some individuals with the terminal male coloration are relatively small. Another problem with this species is that the authorities consider the juveniles and the adults as separate species, wrongly assigning fishing quotas for each. Other species, Pomacanthus zonipectus and Holocanthus passer show signs of over exploitation. Catch has gone down and fishing is taking place farther and deeper than a few years ago. Other commercial species are also being overexploited.

\section{ANTHROPOGENIC THREATS TO CORAL REEF BIODIVERSITY}

\section{CARIBBEAN}

Siltation: The main impact on Caribbean coral reefs of Costa Rica is increased terrigenous sediment loads (Risk et al. 1980, Cortés 1981, 1992, 1994, Cortés \& Risk 1984, 1985, Cortés et al. 1998). At Cahuita, live coral coverage is low and average colony size is large (Fonseca 2003). The amounts of suspended and resuspended sediments are very high, as well as sediments trapped in the massive coral skeletons. Coral growth rates are low, and are significantly inversely correlated with sediment resuspension rates. The increase in terrigenous sediments in this reef is due to deforestation of nearby watersheds (Cortés 1981, Cortés \& Risk 1984, 1985). Terrigenous sediment concentrations had continued to increased and live coral coverage to drop (Cortés 1994, Fonseca et al. 2006a). This, together with other anthropogenic disturbances, e.g. increased tourism and pollution, and natural impacts (but probably exacerbated by human activity) such as bleaching and massive death of organisms, have degraded the reef at Cahuita even more (Cortés 1994, Fonseca \& Nielsen unpubl. data). In 2004 the inner reef crest was studied again, and it was found that live coral has increased at the same time that siltation rates have increased slightly. The rise in both sediment levels and live coral coverage over the last ten years may indicate that other factors besides sedimentation, e.g. D. antillarum dieoffs and the 1991 earthquake, may have had a bigger impact than previously thought in the 
drop in coral cover from 1980 to 1993 (Wyckoff \& Cortés unpubl. data).

Pollution: The coastal zone between Portete and Limón (Fig. 1) are polluted with fecal wastes and garbage, mainly from banana plantations and coastal towns. Analysis between 1981 and 1985 of petroleum pollution indicated that the levels were relatively low, with sporadic events of high concentrations. The highest concentrations were found in the port areas (Mata et al. 1987). In a study done between 2000 and 2002 in the Limón area, the level of petroleum pollution was still low (Acuña-González et al. 2004). High levels of heavy metal pollution in coral skeletons and sediments from reefs, even in "pristine" reefs were found by Guzman \& Jiménez (1992). The sources of the heavy metals may be natural, but mainly they are of anthropogenic origin, including sewage discharges, oil spills (from refineries and tankers), the misuse of agricultural chemicals and fertilizers, and topsoil erosion (Guzman \& García 2002). García-Céspedes et al. (2004) studying trace metals in several coastal areas of Costa Rica, found highest levels of lead in Limón, and intermediate levels of iron, zinc, and copper. Concentrations of PBCs are low in the Limón area (Spongberg 2004).

Impact of tourism: Tourist visitation to the Caribbean coast of Costa Rica, as well as coastal development has increased enormously in the last two decades. This activity has had an impact on the coral reefs of the region, due to trampling of corals and other organisms on the lagoon, and kicking of corals during diving (Cortés 1994, Gove \& Cortés unpubl. data).

\section{PACIFIC COAST AND OFFSHORE ISLANDS}

Siltation: Terrigenous sediments have affected several reefs on the Pacific coast (Cortés \& Murillo 1985), at Bahía Culebra (Jiménez 1998), at Parque Nacional Marino Ballena (Alvarado 2006) and at Golfo Dulce (Cortés 1990a, b, 1991, Cortés et al. 1994, Fonseca 1999, Fonseca et al. 2006b). Sedimentation has increased because of deforestation of the watersheds, road and tourist complexes constructions, and inappropriate agricultural practices (Cortés 1990a, b, Jiménez 1998, Alvarado 2004, 2006). A significant reduction in reef accretion can be observed in reef cores from Golfo Dulce (Fig. 2), and it has been attributed to recent terrigenous sedimentation (last 50 years) as the area was deforested for banana plantation (Cortés et al. 1994, Fonseca 1999).

Extraction of reef organisms: Some species of corals had been extracted for the local curio trade. The populations of Pocillopora eydouxi and of $P$. meandrina, both very attractive branching coral have been reduced because of exploitation (Glynn 1979, Cortés \& Murillo 1985). Extraction of reef fish has severely impacted the populations of some regions (Dominici-Arosemena 1999, Dominici-Arosemena et al. 2005).

Tourism: Coral reefs on the Pacific side of Costa Rica have become important for diving tourism. Touristic activity has direct and indirect effects on the coral reefs (Cortés \& Murillo 1985, Jiménez 1997, 2001a). Direct effects included: coral extraction and damage to colonies by divers and boat anchors. Indirect effects included: over-exploitation of resources (fish, lobster, mollusks) increased sewage and increased sediment loads from coastal alteration (urbanization, road construction).

Pollution: Levels of pollution, e.g. PCB, trace metals and petroleum hydrocarbons are low in Isla del Caño, Bahía Culebra, and Golfo Dulce, with the exception of PCBs, which were high in Golfo Dulce (Acuña \& Murillo 1987, Acuña-González et al. 2004, García-Céspedes et al. 2004, Spongberg 2004).

\section{CURRENT AND POTENTIAL CLIMATE CHANGE IMPACTS}

In June 1983 water temperatures along the Caribbean coast of Costa Rica were between 29 and $35^{\circ} \mathrm{C}$, causing bleaching and death of 
reef organisms (Cortés et al. 1984). One of the most affected species was Acropora palmata, which combined with a Caribbean-wide white band epidemic, eliminated most colonies from the region (Gladfelter 1982, Brukner 2003). In Cahuita, most of the colonies died and recovery has been slow (Cortés et al. 1984, Cortés 1992). More bleaching events were observed in 1992, 1995, 1998, and 2005 (Fonseca \& Nielsen unpubl. data), all coincident with high water temperature. The 1995 bleaching event was particularly severe, affecting and killing several coral species (Jiménez 2001b).

The main natural disturbance affecting coral reefs of the Pacific of Costa Rica had been El Niño warming events. During the 1982-83 El Niño there was extensive coral bleaching (Cortés et al. 1984), resulting in coral death of up to $50 \%$ at Isla del Caño (Guzman et al. 1987), and around 90\% at Isla del Coco (Guzman \& Cortés 1992). The localities with higher mortality had greater sea surface temperature anomalies, longer length of warming, and faster rate of warming (Glynn et al. 1988). Again in 1992 and 1997-1998 there was extensive bleaching of corals, due to warming events. But, in both occasions mortality was lower and recovery was faster than in 1982-83 (Guzman \& Cortés 2001, Jiménez et al. 2001, Jiménez \& Cortés 2001, 2003b).

Coral reefs at Isla del Caño (Fig. 2) were affected during severe phytoplankton blooms in 1985, maybe associated with La Niña. Mass mortality of corals occurred during the bloom down to a depth of $3 \mathrm{~m}$. Mortality due to the dinoflagellate bloom completely eliminated some coral species from shallow reef zones (Guzman et al. 1990). Also related to phytoplankton blooms, extensive bleaching and partial mortality were observed in 2004 at Bahía Culebra where the bloom affected mostly pavoniid corals (Jiménez et al. unpubl. data) and at Santa Elena, where mortality of pocilloporids were observed after a bloom produced mainly by Cochlodinoium polykrikoides (Vargas et al. in prep.).

Mid-day low tidal exposure of Eastern Pacific reefs during La Niña years causes extensive mortality of reef-flat organisms (Eakin \& Glynn 1996). Mortality due to low tides had been observed at Isla del Caño (Guzman 1986) and Corcovado (Cortés \& Jiménez 1996).

\section{MARINE PROTECTED AREAS, MONITORING, AND CONSERVATION MANAGEMENT CAPACITY}

\section{CARIBBEAN}

Marine Protected Areas on the Caribbean coast with coral reefs are: Parque Nacional Cahuita (National Park) and Refugio Nacional de Vida Silvestre Gandoca-Manzanillo (National Wild Life Refuge) (Fig. 1). Monitoring of the Cahuita's seagrasses and coral reefs has been going on since 1999 following the CARICOMP protocol Level I (Fonseca et al. 2006a). Monitoring has been initiated at the reefs at Gandoca-Manzanillo and Isla Uvita with funding from the STA-GCRMN node.

Within the protected areas there is no extraction of corals or live rock, but artisanal fishing is still active in some cases due to local social problems, and in others due to lack of control. Tourism activities began their regulation at Parque Nacional Cahuita, but not for other areas.

\section{PACIFIC}

There are only three protected areas on the Pacific coast of Costa Rica with the marine environment as their main focus of protection, Parque Nacional Marino Las Baulas (Las Baulas National Marine Park), Parque Nacional Marino Ballena (Ballena National Marine Park) and Área de Conservación Marina Isla del Coco (Isla del Coco Marine Conservation Area) (Fig. 2). Other coral reefs areas are protected in the marine portions of parks or conservation areas, from North to South: , Parque Nacional Santa Rosa, Reserva Absoluta Cabo Blanco (Absolute Reserve), Parque Nacional Manuel Antonio, Reserva Biológica Isla del Caño (Biological Reserve), and Parque Nacional Corcovado (Fig. 2).

Monitoring is going on at Isla del Caño, Parque Nacional Marino Ballena, and is starting 
at Isla del Coco. Another area that is being monitored is Bahía Culebra (Fig. 2), and there are plans to monitor the reefs of Golfo Dulce in the South, but these last two are not protected areas. A national coral reef monitoring plan is being developed at the present time (2009).

Within the protected areas there is no extraction of corals or live rock, but there is still reef fish extraction fishing going on at Área de Conservación Guanacaste. Commercial fishing has been controlled in most parks, but it still goes on at the outer marine limits of the protected areas, that should be considered as buffer zones. Tourism is being regulated at Isla del Caño and Isla del Coco, but not in other areas.

\section{GOVERNMENT POLICIES, LAWS AND LEGISLATION}

The Costa Rican government does not have any specific policy regarding coral reefs (Cajiao- Jiménez 2003) or monitoring activities. There are laws regulating the activity in the coastal zone, pollution inland and sea, fisheries, wildlife protection, and biodiversity use and conservation. All touch coral reefs indirectly, which is the first problem, and second, each one is enforced by a different government institution. This results in lack of enforcement, institutional overlap and negligence. Only the Ministerio de Ambiente y Energía (MINAE, Ministry of the Environment), through its Sistema Nacional de Áreas de Conservación (SINAC, National System of Conservation Areas) protects the coral reefs inside protected areas.

A decree banning the extraction of corals and other reef organisms in Costa Rican waters was drafted and submitted in September 2005 but has not been signed. If this decree is signed corals and many other reefs organisms, e.g. sponges, non-commercial molluscs, and octocorals, among others, could only be collected for scientific research.

\section{GAPS IN CURRENT MONITORING AND CONSERVATION CAPACITY}

Coral reef monitoring is restricted to one site on the Caribbean (Parque Nacional Cahuita) and two on the Pacific coast: Bahía Culebra and Isla del Caño. But on the Caribbean, two new reefs at Refugio Nacional de Vida Silvestre Gandoca-Manzanillo and Isla Uvita were started. On the Pacific, the reefs at Islas Murciélago, Golfo Dulce, and at Isla del Coco need to be included. A national coral reef monitored program should be implemented and financial support included.

Conservation capacity is moderate because of finite funding. With the exception of Isla del Coco, protection of coral reefs is restricted to the immediate areas that the park rangers can watch from the post. To aggravate the problem of coral reef conservation, in many cases the causes of reef degradation originate outside the parks' boundary, e.g., sediments coming down from deforested mountains of adjacent watersheds; or coral death is due to El Niño warming events.

\section{CONCLUSIONS AND RECOMMENDATIONS FOR CORAL REEF CONSERVATION}

Costa Rica has coral reefs on the Caribbean and Pacific coasts (coast and off-shore islands). Most reefs are within protected areas, but management and conservation is limited because of inadequate funding, and because some of the main problems are natural (warming events) or originate outside the protected areas (sediments from adjacent watersheds). Outside the protected areas there are regulations to improve land use, for example, the need of keeping a belt of forest along rivers, but this is not always applied. This has resulted in degraded reefs in several areas due to chronic siltation, for example, Cahuita, Parque Nacional Marino Ballena and Golfo Dulce. In other areas, especially on 
the Pacific live coral has been significantly reduced in the last two decades due to El Niño. In general terms the coral reefs of Costa Rica are recovering, but the degree of human activity directly affect this recovery.

Extraction of any kind of reef organisms, including the so called "live rock" must be completely prohibited and banned in all reef areas, or at least within the protected areas.

Tourism and fishing in coral reefs areas must be regulated and dive sites designated following scientific criteria to define the carrying capacity. Reef sites should be permanently marked with mooring buoys. A diving etiquette, with coral conservation and protection as its main objective, must be elaborated and implemented. Fishing of any kind should not be allowed in protected areas.

New marine conservation projects should include the surrounding areas or buffer zones, specially the large watersheds, to stop or reduce the input of sediments and pollutants. Also, more outreach to the general public, direct and indirect users of the reef, and government officials is needed. The categories of marine protection should be redefined or updated from previous management plans, considering the current knowledge on integrated coastal and marine management. The conclusions of the conservation gap analysis recently published (SINAC 2009) must be implemented, with the expansion and creation of new marine protected areas, and the implementation of the new protection categories (Executive Decree 34433). Governamental jurisdiction outside marine protected areas, inland and offshore, should be defined in order to acquire a higher institutional compromise.

\section{ACKNOWLEDGMENTS}

Funding was provided by the Vicerrectoría de Investigación, Universidad de Costa Rica; Consejo Nacional de Investigaciones Científicas y Tecnológicas (CONICIT); UNEP Caribbean Monitoring Project through the STA-GCRMN node at INVEMAR, Colombia; Ecodesarrollo Papagayo; and M. Tupper.
Logistic support was provided by the Centro de Investigación en Ciencias del Mar y Limnología (CIMAR, UCR); Hotel Ecoplaya; Instituto Costarricense de Turismo (ICT); Sistema Nacional de Áreas de Conservación (SINAC); and UnderSea Hunter. The reviews by Ian G. Macintyre, Tim Rixen, and especially Héctor Guzman are geatly appreciated.

\section{RESUMEN}

Costa Rica tiene comunidades coralinas y arrecifes en la costa Caribe y del lado Pacífico a lo largo de la costa y en islas mar afuera). Arrecifes de franja y de parche, bancos carbonatados y una cresta de algas coralinas incipiente están presentes en la sección sur de la costa Caribe. Comunidades coralinas, arrecifes y colonias de coral aisladas se encuentran a lo largo de todo el Pacífico de Costa Rica. Los arrecifes coralinos han sido impactados seriamente en los últimos 30 años, principalmente por sedimentos en el Caribe y algunos arrecifes del Pacífico, y por el calentamiento durante el Fenómeno de El Niño-Oscilación Sureña en el Pacífico. Tres sitios en el Caribe y otros tres en el Pacífico están siendo monitoreados. Después de reducciones significativas en la cobertura de coral vivo en la década de 1980, tanto en el Caribe como en el Pacífico, la mayoría de los arrecifes se está recuperando. El gobierno de Costa Rica es consciente de la importancia de los arrecifes coralinos y de otros ecosistemas marinos, y en años recientes han implementado (o están en proceso de aprobación) varios decretos para la protección de los arrecifes. Pero, hay limitación de fondos y personal para su adecuado manejo y protección. Se necesita más divulgación de información sobre los arrecifes coralinos al público en general y usuarios de los mismos; de nuevo, la limitación de fondos restringe lo que se puede hacer.

Palabras clave: arrecifes coralinos, Costa Rica, monitoreo, GCRMN, conservación, manejo.

\section{REFERENCES}

Acuña, J.A. \& M.M. Murillo. 1987. La contaminación por hidrocarburos de petróleo en la Isla del Caño. Ing. Cienc. Quím. 11: 95-98.

Acuña-González, J.A., J.A. Vargas-Zamora, E. GómezRamírez \& J. García-Céspedes. 2004. Hidrocarburos de petróleo, disueltos y dispersos, en cuatro ambientes costeros de Costa Rica. Rev. Biol. Trop. 52: 43-50.

Alvarado, J.J. 2004. Descripción de las comunidades arrecifales del Parque Nacional Marino Ballena, Pacífico central-sur de Costa Rica. Tesis de Licenciatura, Universidad de Costa Rica. San Pedro, Costa Rica. 
Alvarado, J.J. 2006. Factores físico-químicos y biológicos que median en el desarrollo de los arrecifes y comunidades coralinas del Parque Nacional Marino Ballena, Pacífico sur, Costa Rica. Master Thesis, Universidad de Costa Rica. San Pedro, Costa Rica.

Alvarado, J.J., J. Cortés \& E. Salas. 2004. Status of the sea urchin Diadema antillarum Philippi (Echinodermata: Echinoidea) at Cahuita National Park (1977-2003), Costa Rica. Carib. J. Sci. 40: 257-259.

Alvarado, J.J., J. Cortés, C. Fernández \& J. Nivia. 2005. Coral communities and reefs of Ballena Marine National Park, Pacific coast of Costa Rica. Cienc. Mar. 31: 641-651.

Alvarado, J.J., C. Fernández \& J. Cortés. 2009. Water quality conditions on coral reefs at the Marino Ballena National Park, Pacific Costa Rica. Bull. Mar. Sci. 84: $137-152$.

Bakus, G.J. 1975. Marine zonation and ecology of Cocos Island, off Central America. Atoll Res. Bull. 179: $1-11$.

Bezy, M.B., C. Jiménez, J. Cortés, A. Segura, A. León, J.J. Alvarado, C. Gillén \& E. Mejía. 2006. Contrasting Psammocora-dominated coral communities in Costa Rica, Tropical Eastern Pacific. Proc. 10th Int. Coral Reef Symp. 1: 376-381.

Bruckner, A.W. 2003. Proceedings of the Caribbean Acropora Workshop: Potential application of the U.S. endangered species act as a conservation strategy. NOAA Technical Mem. NMFS-OPR-24, Silver Springs, Maryland, USA

Cairns, S.D. 1991. A revision of the ahermatypic Scleractinia of the Galápagos and Cocos Islands. Smithson. Contr. Zool. 504: 1-33.

Cajiao-Jiménez, M.V. 2003. Régimen legal de los recursos marinos y costeros en Costa Rica. Editorial IPECA, San José Costa Rica.

Cortés, J. 1981. The coral reef at Cahuita, Costa Rica, a reef under stress. Master Thesis, McMaster University, Hamilton, Ontario, Canada.

Cortés, J. 1990a. Coral reef decline in Golfo Dulce, Costa Rica, Eastern Pacific: anthropogenic and natural disturbances. Ph.D. Dissertation, University of Miami, Miami, Florida, USA.

Cortés, J. 1990b. The coral reefs of Golfo Dulce, Costa Rica: Distribution and community structure. Atoll Res. Bull. 344: 1-37.
Cortés, J. 1991. Los arrecifes coralinos de Golfo Dulce, Costa Rica: aspectos geológicos. Rev. Geol. Amér. Central 13: 15-24.

Cortés, J. 1992. Los arrecifes coralinos del Refugio Nacional de Vida Silvestre Gandoca-Manzanillo, Limón, Costa Rica. Rev. Biol. Trop. 40: 325-333.

Cortés, J. 1994. A reef under siltation stress: a decade of degradation, p. 240-246. In R.N. Ginsburg (compiler). Proc. Colloquium on global aspects of coral reefs: Health, hazards and history, 1993. RSMAS, University of Miami, Miami, Florida, USA.

Cortés, J. 1996/1997. Comunidades coralinas y arrecifes del Área de Conservación Guanacaste, Costa Rica. Rev. Biol. Trop. 44/45: 623-625.

Cortés, J. 1998. Componente Marino, p. 1-24. In J.A. Vargas (ed.) Planificación y manejo de bahías y áreas costeras fuertemente contaminadas del Gran Caribe. Estudio de caso: Puerto Limón, Costa Rica. Informe Final, Proyecto Regional GEF/RLA/G41.

Cortés, J. 2008. Historia de la investigación marina de la Isla del Coco, Costa Rica. Rev. Biol. Trop. 56 (Suppl. 2): $1-18$

Cortés, J. \& H.M. Guzman. 1985. Arrecifes coralinos de la costa Atlántica de Costa Rica. Brenesia 23: 275-292.

Cortés, J \& H.M. Guzman. 1998. Organismos de los arrecifes coralinos de Costa Rica: Descripción, distribución geográfica e historia natural de los corales zooxantelados (Anthozoa: Scleractinia) del Pacífico. Rev. Biol. Trop. 46: 55-92.

Cortés, J. \& C.E. Jiménez. 1996. Coastal-marine environments of Parque Nacional Corcovado, Puntarenas, Costa Rica. Rev. Biol. Trop. 44: 35-40.

Cortés, J. \& C.E. Jiménez. 2003a. Past, present and future of the coral reefs of the Caribbean coast of Costa Rica, p. 223-239. In J. Cortés (ed.). Latin American Coral Reefs. Elsevier Science B.V., Amsterdam, The Netherlands.

Cortés, J. \& C.E. Jiménez. 2003b. Corals and coral reefs of the Pacific of Costa Rica: History, research and status, p. 361-385. In J. Cortés (ed.). Latin American coral reefs. Elsevier Science B.V., Amsterdam, The Netherlands.

Cortés, J. \& M.M. Murillo. 1985. Comunidades coralinas y arrecifes del Pacífico de Costa Rica. Rev. Biol. Trop. 33: 197-202. 
Cortés, J. \& M.J. Risk. 1984. El arrecife coralino del Parque Nacional Cahuita, Costa Rica. Rev. Biol. Trop. 32: 109-121.

Cortés, J. \& M.J. Risk. 1985. A reef under siltation stress: Cahuita, Costa Rica. Bull. Mar. Sci. 36: 339-356.

Cortés, J., M.M. Murillo, H.M. Guzman \& J. Acuña. 1984. Pérdida de zooxantelas y muerte de corales y otros organismos arrecifales en el Atlántico y Pacífico de Costa Rica. Rev. Biol. Trop. 32: 227-231.

Cortés, J., R. Soto, C. Jiménez \& A. Astorga. 1992. Death of intertidal and coral reef organisms as a result of a 7.5 earthquake. Proc. 7th Int. Coral Reef Symposium 1: $235-240$.

Cortés, J., I.G. Macintyre \& P.W. Glynn. 1994. Holocene growth history of an Eastern Pacific fringing reef, Punta Islotes, Costa Rica. Coral Reefs 13: 65-73.

Cortés, J., A.C. Fonseca, M. Barrantes \& P. Denyer. 1998. Type, distribution and origin of sediments of the Gandoca-Manzanillo National Wildlife Refuge, Limón, Costa Rica. Rev. Biol. Trop. 46: 251-256.

Dominici-Arosemena, A. 1999. Estructura poblacional de los peces de arrecifes del Golfo de Papagayo, Guanacaste, con énfasis en las especies de mayor importancia comercial como ornamentales. Master Thesis, University of Costa Rica, San Pedro, Costa Rica.

Dominici-Arosemena, A., E. Brugnoli-Olivera, J. CortésNúñez, H. Molina-Ureña \& M. Quesada-Alpízar. 2005. Community structure of Eastern Pacific reef fishes (Gulf of Papagayo, Costa Rica). Tecnociencia 7: 19-41.

Eakin, C.M. \& P.W. Glynn. 1996. Low tidal exposure and reef mortalities in the Eastern Pacific. Coral Reefs 15: 120 .

Fernández, C. 2007. Propagación del alga Caulerpa sertularioides (Chlorophyta) en Bahía Culebra, Golfo de Papagayo, Pacífico norte de Costa Rica. Master Thesis, University of Costa Rica. San Pedro, Costa Rica.

Fernández, C. \& J.J. Alvarado. 2004. El arrecife coralino de Punta Cocles, costa Caribe de Costa Rica. Rev. Biol. Trop. 52: 121-129.

Fernández, C. \& J. Cortés. 2005. Caulerpa sertularioides, a green alga spreading aggressively over coral reef communities in Culebra Bay, North Pacific of Costa Rica. Coral Reefs, Reef Site 24: 10.

Fonseca E., A.C. 1999. Bioerosión y bioacreción en arrecifes coralinos del Pacífico sur de Costa Rica. Master
Thesis, University of Costa Rica, San Pedro, Costa Rica.

Fonseca E., A.C. 2003. A rapid assessment at Cahuita National Park, Costa Rica, 1999 (Part 1: stony corals and algae). Atoll Res. Bull. 496: 248-257.

Fonseca E., A.C. \& C. Gamboa. 2003. A rapid assessment at Cahuita National Park, Costa Rica, 1999 (Part 2: reef fishes). Atoll Res. Bull. 496: 258-267.

Fonseca E., A. C., E. Salas \& J. Cortés. 2006a. Monitoreo del arrecife coralino Meager Shoal, Parque Nacional Cahuita (sitio CARICOMP). Rev. Biol. Trop. 54: 755-763.

Fonseca E., A.C., H.K. Dean and J. Cortés. 2006b. Noncolonial macro-borers as indicators of coral reef status in the South Pacific of Costa Rica. Rev. Biol. Trop. 54: 101-115.

García-Céspedes, J., J.A. Acuña-González \& J.A. VargasZamora. 2004. Metales traza en sedimentos de cuatro ambientes costeros de Costa Rica. Rev. Biol. Trop. 52: $51-60$.

Gladfelter, W.B. 1982. White-band disease in Acropora palmata: implications for the structure and growth of shallow reefs. Bull. Mar. Sci. 32: 639-643.

Glynn, P.W. 1979. Climatic cycles may affect reef growth. Smithsonian Tropical research Institute, Cont. Res 26: 4 .

Glynn, P.W., E.M. Druffel \& R.B. Dunbar. 1983. A dead Central American coral reef tract: possible link with the Little Ice Age. J. Mar. Res. 41: 605-637.

Glynn, P.W., J. Cortés, H.M. Guzman \& R.H. Richmond. 1988. El Niño (1982-83) associated coral mortality and relationship to sea surface temperature deviations in the Tropical Eastern Pacific. Proc. 6th Int. Coral Reef Symposium 3: 237-243.

Guzman, H.M. 1986. Estructura de la comunidad arrecifal de la Isla del Caño, Costa Rica, y el efecto de perturbaciones naturales severas. Master Thesis, University of Costa Rica, San Pedro, Costa Rica.

Guzman, H.M. 1988. Distribución y abundancia de organismos coralívoros en los arrecifes coralinos de la Isla del Caño, Costa Rica. Rev. Biol. Trop. 36: 191-207.

Guzman, H.M. \& J. Cortés. 1989. Coral reef community structure at Caño Island, Pacific Costa Rica. P.S.Z.N.I: Mar. Ecol. 10: 23-41. 
Guzman, H.M. \& J. Cortés. 1992. Cocos Island (Pacific of Costa Rica) coral reefs after the 1982-83 El Niño disturbance. Rev. Biol. Trop. 40: 309-324.

Guzman, H.M. \& J. Cortés. 2001. Changes in reef community structure after fifteen years of natural disturbances in the Eastern Pacific (Costa Rica). Bull. Mar. Sci.: 69: 133-149.

Guzman, H.M. \& J. Cortés. 2007. Reef recovery 20-yr after the 1982-83 El Niño massive mortality. Mar. Biol. 151: 401-411.

Guzman, H.M. \& E.M. García. 2002. Mercury levels in coral reefs along the Caribbean coast of Central America. Mar. Poll. Bull. 44: 1415-1420.

Guzman, H.M. \& C.E. Jiménez. 1992. Contamination of coral reefs by heavy metals along the Caribbean coast of Central America (Costa Rica and Panama). Mar. Poll. Bull. 24: 554-561.

Guzman, H.M., J. Cortés, R.H. Richmond \& P.W. Glynn. 1987. Efectos del fenómeno de "El Niño-Oscilación Sureña” 1982/83 en los arrecifes de la Isla del Caño, Costa Rica. Rev. Biol. Trop. 35: 325-332.

Guzman, H.M., J. Cortés, P.W. Glynn \& R.H. Richmond. 1990. Coral mortality associated with dynoflagellate blooms in the eastern Pacific (Costa Rica and Panama). Mar. Ecol. Prog. Ser. 60: 299-303.

Hebbeln, D. \& J. Cortés. 2001. Sedimentation in a tropical fjord: Golfo Dulce, Costa Rica. Geo-Mar. Lett. 20: 142-148.

Hebbeln, D., D. Beese \& J. Cortés. 1996. Morphology and sediment structure in Golfo Dulce, Costa Rica. Rev. Biol. Trop. 44: 1-10.

Jiménez, C.E. 1997. Corals and coral reefs of Culebra Bay, Pacific coast of Costa Rica: anarchy in the reef. Proc. 8th Int. Coral Reef Symposium 1: 329-334.

Jiménez, C.E. 1998. Arrecifes y comunidades coralinas de Bahía Culebra, Pacífico norte de Costa Rica (Golfo de Papagayo). Master Thesis, University of Costa Rica, San Pedro, Costa Rica.

Jiménez, C.E. 2001a. Arrecifes y ambientes coralinos de Bahía Culebra, Pacífico de Costa Rica: aspectos biológicos, económico-recreativos y de manejo. Rev. Biol. Trop. 49: 215-231.

Jiménez, C.E. 2001b. Bleaching and mortality of reef organisms during a warming event in 1995 at the Caribbean coast of Costa Rica. Rev. Biol. Trop. 49: 233-238.
Jiménez, C.E. \& J. Cortés. 2001. Effects of the 1991-92 El Niño on scleractinian corals of the central Pacific coast of Costa Rica. Rev. Biol. Trop. 49: 239-250.

Jiménez, C.E. \& J. Cortés. 2003a. Growth of seven species of scleractinian corals in an upwelling environment of the eastern Pacific (Golfo de Papagayo, Costa Rica). Bull. Mar. Sci. 72: 187-198.

Jiménez, C.E. \& J. Cortés. 2003b. Coral cover change associated to El Niño, eastern Pacific, Costa Rica, 1992-2001. P.S.Z.N.: Mar. Ecol. 24: 179-192.

Jiménez, C.E., J. Cortés, A. León \& E. Ruiz. 2001. Coral bleaching and mortality associated with El Niño $1997 / 98$ event in an upwelling environment at the Eastern Pacific (Gulf of Papagayo, Costa Rica). Bull. Mar. Sci. 69: 151-169.

Jiménez, C., J. Cortés \& E. Ruiz. 2003. Re-evaluación de los ambientes coralinos de Bahía Culebra (19942003). Ecodesarrollo Papagayo, unpubl. rept. 27 p.

Lessios, H.A., D.R. Robertson \& J.D. Cubit. 1984. Spread of Diadema mass mortality through the Caribbean. Science 226: 335-337.

Macintyre, I.G., P.W. Glynn \& J. Cortés. 1992. Holocene reef history in the Eastern Pacific: mainland Costa Rica, Caño Island, Cocos Island, and Galápagos Islands. Proc. 7th Int. Coral Reef Symp. 2: 11741184.

Mata, A., J.A. Acuña, M.M. Murillo \& J. Cortés. 1987. La contaminación por petróleo en el Caribe de Costa Rica: 1981-1985. Carib. J. Sci. 23: 41-49.

McCreary, J.P., H.S. Lee \& D.B. Enfield. 1989. The response of the coastal ocean to strong offshore winds, with application to circulations in the Gulfs of Tehuantepec and Papagayo. J. Mar. Res. 47: 81-109.

Murillo, M.M. \& J. Cortés. 1984. Alta mortalidad en la población del erizo de mar Diadema antillarum en el Parque Nacional Cahuita, Limón, Costa Rica. Rev. Biol. Trop. 32: 167-169.

Myhre, S. \& A. Acevedo-Gutiérrez. 2007. Recovery of sea urchin Diadema antillarum populations is correlated to increase coral cover and reduced macroalgal cover. Mar. Ecol. Prog. Ser. 329: 205-210.

Phillips, P.C. \& M. Perez-Cruet. 1984. A comparison survey of reef fishes in Caribbean and Pacific Costa Rica. Rev. Biol. Trop. 32: 95-102.

Risk, M.J., M.M. Murillo \& J. Cortés. 1980. Observaciones biológicas preliminares sobre el arrecife coralino en el 
Parque Nacional Cahuita, Costa Rica. Rev. Biol. Trop. 28: 361-382.

SINAC (Sistema Nacional de Áreas de Conservación). 2009 GRUAS II: Propuesta de Ordenamiento Territorial para la conservación de la biodiversidad en Costa Rica. Vol. III. Análisis de vacíos en la representatividad e integridad de la biodiversidad de los sistemas marinos y costeros. San José, Costa Rica. 60 p.
Spongberg, A.L. 2004. PCB Contamination in surface sediments in the coastal waters of Costa Rica. Rev. Biol. Trop. 52: 1-10.

Valdez, M.F. \& C.R. Villalobos. 1978. Distribución especial, correlación con el sustrato y grado de agregación en Diadema antillarum Philippi (Echinodermata: Echinoidea) Rev. Biol. Trop. 26: 237-245. 